Hwa-kou King MD, ${ }^{* \dagger}$ Chang-Si Xiao MD, $†$ Daniel J. Wooten $\mathrm{MD}^{*}$

\section{Prolongation of epidural bupivacaine analgesia with glycerin}

chronic pain, this novel approach may have other clinical applications such as the relief of labour or postoperative pain.

Glycerin has been used as a drug carrier/depot, but never with local anaesthestics. This study was an attempt to use the slow drug release mechanism to prolong the anaesthetic effects of bupivacaine in epidural block. Twenty-seven adults with cancer pain were prospectively selected according to their primary lesions and problems, but their allocation to study groups was randomized. Group $I(n=13)$, received $5 \mathrm{ml}$ bupivacaine, $0.125 \%$ in normal saline via a previous implanted epidural catheter. When the pain returned to its original intensity, the same amount of the same strength anaesthetic dissolved in $50 \%$ glycerin was given via the same catheter. Group $I I(n=14)$ received the same solutions, but in the reverse order. Also five patients in each group received plain $50 \%$ glycerin prior to administration of the anaesthetic solutions to serve as controls. The pharmacological effects were assessed by the blinded observers. Analgesia produced with glycerin solution was prolonged compared with the saline solution (12.2 vs 7.2 and 11.6 vs $7.4 \mathrm{hr}$, $P<0.01$ ). The order of giving the solution did not produce any differences. Plan $50 \%$ glycerin did not produce analgesic effects. Neither motor blockade nor other adverse effects or complications were observed in either group. It was concluded that $0.125 \%$ bupivacaine in $50 \%$ glycerin administered epidurally is not neurotoxic. The prolongation of analgesia observed is attributed to the slow release of bupivacaine from the glycerin base which functions as drug depot. In addition to relief of

\section{Key words}

ANAESTHETICS: local, bupivacaine;

PAIN: chronic.

From the Departments of Anesthesiology of *King/Drew

Medical Center, Charles R. Drew University of Medicine and Science, Los Angeles, CA. †Zhong-Shan Hospital, Shanghai Medical University, Shanghai, and $\ddagger$ China Medical Center, Taipei, Taiwan, China.

Presented in part at the 66th Congress of International Anesthesia Research Society, San Francisco, March 13-17, 1992.

Address correspondence to: Dr. Hwa-kou King, Department of Anesthesiology, King/Drew Medical Center, 12021 Wilmington Avenue, Los Angeles, CA 90059, U.S.A. Accepted for publication Ilth February, 1993.
La glycérine sert de vecteur et de réservoir à bien des substances médicamenteuses mais on ne l'a jamais utilisée avec des anesthésiques locaux. Cette étude veut tirer profit du mécanisme de libération retardée pour prolonger les effets de la bupivacaïne pendant le bloc épidural. Vingt-sept adultes souffrant de douleur cancéreuse font partie de cette étude randomisée et prospective. Ils sont distribués en trois groupes. Le groupe I (n =13) reçoit bupivacaïne $0,125 \%$ dans le soluté physiologique $5 \mathrm{ml}$ par un cathéter préalablement implanté. Lorsque la douleur revient à son intensité initiale, on injecte par le cathéter épidural la même quantité et la même concentration de l'anesthésique dissout dans la glycérine $50 \%$. Le groupe II reçoit les mêmes solutions, mais dans l'ordre inverse. Cinq patients de chaque groupe reçoivent seulement de la glycérine $50 \%$ par la même voie avant l'administration de l'anesthésique et servent ainsi de contrôles. Les effets sont évalués par un observateur neutre. Lanalgésie produite par la solution glycérinée dure plus longtemps que la solution préparée avec le soluté physiologique $(12,2$ vs 7,2 et 11,6 vs $7,4 P<0,01)$. Lordre de l'administration n'a pas d'importance. La glycérine $50 \%$ seule n'a pas d'activité analgésique. On n'a pas observé de bloc moteur ni d'effets défavorables dans aucun des groupes. On en conclut que la bupivacaïne 0,125\% dans la glycérine $50 \%$ ne cause pas de neurotoxicité en administration épidurale. La prolongation de l'effet est attribuée au fait que la glycérine, qui agit comme un réservoir, libère lentement son contenu de bupivacaïne. En plus de son efficacité contre la douleur chronique, on peut entrevoir pour cette modalité thérapeutique de nouvelles applications comme le soulagement de la douleur obstétricale et postopératoire.

Glycerin has long been used with phenol as a drug carrier/depot for control of late-stage intractable pain for cancer patients. ${ }^{1}$ However, to our knowledge, glycerin has never been used in conjunction with a local anaesthetic agent to prolong its pharmacological effects. Our study is an attempt to use this slow drug release mechanism to extend further the analgesic effects of a popular longacting local anaesthetic agent, bupivacaine, in a commonly used technique, epidural block. 


\section{Methods}

Following institutional Human Investigation Committee approval and patient informed consent, 15 adult patients at Zhong-Shan Hospital in Shanghai, and 12 adult patients at China Medical Center in Taipei, China were enrolled into this study for relief of cancer pain. Patients were selected prospectively according to their primary lesions and problems, but their allocation to the study groups was random. Patients who were receiving other active pain treatment, whether employing a pharmacological or non-pharmacological approach, or those with altered mentalities were excluded. Patients in Group I $(n=13)$ received $5 \mathrm{ml}$ bupivacaine, $0.125 \%$ in normal saline via a previously implanted epidural catheter. Injections were followed by irrigation of the catheter with $0.2 \mathrm{ml}$ saline (the dead space of the catheter was previously evaluated and never exceeded $0.16 \mathrm{ml}$ ). Later, when the pain returned to its original intensity, the same amount of the same strength anaesthetic dissolved in 50\% glycerin was administered via the same catheter. Patients in Group II $(n=14)$ also received both aqueous and glycerol solutions, but in reverse order. All patients were in supine position during and for $30 \mathrm{~min}$ following injections. Five patients in each group received plain 50\% glycerin one day prior to the administration of anaesthetic solution to serve as a control. The pharmacological effects were assessed every minute for $30 \mathrm{~min}$, and thereafter, every $30 \mathrm{~min}$ by evaluation of the intensity and duration of sensory and motor blockade employing visual analogue scale ${ }^{2,3}$ and modified Bromage scale. ${ }^{4}$ The observers as well as the patients were blinded to the solutions given. Patients' vital signs were closely monitored during the study. Results obtained were analyzed by Student's t test. A $P$ value $<0.05$ was considered to be significant.

\section{Results}

The two groups were demographically compatible; patients did not differ with regard to sex, age, weight and height (Table I). The sites of their primary lesions and epidural catheter placement are shown in Table II. Both groups were also compatible in this regard. The mean times of onset for the saline and glycerol solutions were $8.8 \pm 1.3 \mathrm{~min}$ vs $9.2 \pm 1.1 \mathrm{~min}$ and $9.4 \pm 1.8 \mathrm{~min}$ vs $9.9 \pm 1.4 \mathrm{~min}$, respectively for Group I and Group II (NS). The median spread of anaesthetic was 5.4 and 5.1 segments for the saline solution and 5.3 and 5.2 segments for the glycerol solution (NS). The mean durations of analgesia were $7.2 \pm 1.6$ and $7.4 \pm 1.2 \mathrm{hr}$ for the saline solutions, and $12.2 \pm 1.6$ and $11.6 \pm 1.7$ for the glycerol solutions respectively $(P<0.01)$ regardless of the sequence of drug administration (Table III). The quality of analgesia produced by saline solution and glycerol so-
TABLE I Patient characteristics

\begin{tabular}{lcc}
\hline & Group $I(n=13)$ & Group $I I(n=14)$ \\
\hline Sex $(\mathrm{M} / \mathrm{F})$ & $8 / 5$ & $9 / 5$ \\
Age $(\mathrm{yr})^{*}$ & $66 \pm 6.6$ & $68 \pm 4.3$ \\
Height $(\mathrm{cm})^{*}$ & $165 \pm 2.2$ & $167 \pm 1.6$ \\
Weight $(\mathrm{kg})^{*}$ & $62 \pm 4.3$ & $65 \pm 3.7$ \\
\hline
\end{tabular}

*Mean $\pm S D$.

TABLE II Sites of primáry lesion and epidural catheter

\begin{tabular}{|c|c|c|c|}
\hline \multicolumn{2}{|l|}{ Sites } & \multirow{2}{*}{$\begin{array}{l}\text { Group I } \\
(n=13)\end{array}$} & \multirow{2}{*}{$\begin{array}{l}\text { Group II } \\
(n=14)\end{array}$} \\
\hline Lesion & Catheter & & \\
\hline Bladder & $\mathrm{L}_{4-5}$ & 2 & 1 \\
\hline Breast & $T_{6-7}$ & 2 & 2 \\
\hline Liver & $T_{9-10}$ & 2 & 2 \\
\hline Lung & $T_{7-8}$ & 2 & 2 \\
\hline Pancreas & $T_{9-10}$ & 0 & 1 \\
\hline Prostate & $\mathrm{L}_{4-5}$ & 0 & 1 \\
\hline Rectum & $\mathrm{L}_{4-5}$ & 5 & 4 \\
\hline Testis & $\mathrm{L}_{4-5}$ & 0 & 1 \\
\hline
\end{tabular}

TABLE III Pharmacological effects

\begin{tabular}{|c|c|c|c|c|}
\hline & \multicolumn{2}{|l|}{ Group I } & \multicolumn{2}{|l|}{ Group II } \\
\hline & Saline & Glycerin & Glycerin & Saline \\
\hline \multicolumn{5}{|l|}{ Analgesia } \\
\hline - Onset (min) ${ }^{* 1}$ & $8.8 \pm 1.3$ & $9.2 \pm 1.1$ & $9.9 \pm 1.4$ & $9.4 \pm 1.8$ \\
\hline - Duration $(\mathrm{hr})^{* 2}$ & $7.2 \pm 1.6$ & $12.2 \pm 1.6$ & $11.6 \pm 1.7$ & $7.4 \pm 1.2$ \\
\hline Spread (segments) ${ }^{\prime}$ & 5.4 & 5.3 & 5.2 & 5.1 \\
\hline \multicolumn{5}{|c|}{ Quality (VAS) } \\
\hline$-0-1$ & 10 & 11 & 11 & 10 \\
\hline$-2-3$ & 2 & 1 & 2 & 2 \\
\hline$-4-5$ & 1 & 1 & 1 & 2 \\
\hline$-6-10$ & 0 & 0 & 0 & 0 \\
\hline Motor blockade & 0 & 0 & 0 & 0 \\
\hline
\end{tabular}

*Mean $\pm \mathrm{SD} ; \dagger=$ Median.

I Not significant between agents or groups.

${ }^{2}$ Statistical significant between agents $(P<0.01)$; not significant between groups.

lution was similar (NS). Most patients in both groups obtained satisfactory pain relief (VAS $<5$ ). No clinical signs of nerve block were detected after plain glycerin solution. Neither motor blockade nor any adverse reactions were observed in either group. Vital signs were stable in both groups. Three patients' arterial blood pressure decreased more than $20 \mathrm{mmHg}$ but less than one-third of their base line readings. They all responded promptly to fluid infusion or a small dose $(5 \mathrm{mg}$ ) of ephedrine. 


\section{Discussion}

Glycerin is a naturally occurring trihydric alcohol with a high viscosity and osmolarity. It is miscible with water and alcohol and has been used as a vehicle or stabilizer for drugs. ${ }^{5}$ Glycerin absorbs water and, therefore, in high concentrations, is somewhat dehydrating and irritating to exposed tissues. ${ }^{5}$ The $50 \%$ glycerin with bupivacaine solution we used has a $\mathrm{pH}$ value of 6.0 . Glycerin is part of the neutral fat (triglyceride) molecule and thus a normal metabolic intermediate in animals and human beings. It is known that glycerol is converted by liver to glycogen and other carbohydrates. ${ }^{6}$ Glycerin has been given orally ( 50 or $75 \%$ ) or intravenously (10\%) to reduce intracranial or intraocular pressure. ${ }^{5,7,8}$ It also may be applied topically to reduce corneal oedema. Local injection of glycerin with or without teflon has long been used for various purposes in otolaryngology. ${ }^{9-12}$ In anaesthesia, the use of glycerin and phenol for the control of intractable cancer pain was popularized by Maher, ' who, in 1955, described the subarachnoid administration of phenol in glycerin to produce a chemical rhizotomy. Furthermore, pain relief from trigeminal neuralgia by selective destruction of the pain-bearing nerve fibres has been achieved by the instillation of glycerin among the trigeminal rootlets (percutaneous retrogasserian glycerol rhizolysis). ${ }^{13}$

In this study, we used $50 \%$ glycerin solution because it is a physiologically occurring substance and therefore likely to be safe and harmless. It is a markedly diluted solution thus easy to inject through an elongated epidural catheter and will not irritate the exposed tissues or cause any complications by inadvertent intravascular injection. ${ }^{5-9}$ The observed prolongation of analgesia was attributed to the slow release of the local anaesthetic agent from the glycerin base which functions as a drug depot, that ensures the availability of an effective drug concentration within the epidural space. Langerman et al. employed the same slow release mechanism and reported the use of lipid (iophendylate) solution for prolongation of spinal anaesthesia ${ }^{14}$ as well as epidural anaesthesia. ${ }^{15}$ Mashima et al. ${ }^{16}$ used liposome for the same purpose. It appears that this controlled-release formulation concept has been grasped all over the world.

As concentrated glycerin possesses a neurolytic effect, ${ }^{13}$ the prolongation of analgesia could have been due to neurotoxicity. This is very unlikely, as the pain relief obtained was only temporary and we have not observed any neurological sequelae in any of our patients. Nonetheless, this possibility deserves further investigation. We therefore have included five patients in each group, who were given plain glycerin prior to the anaesthetic solutions, during the latter part of the study. However, at the time this manuscript was prepared, all our patients are alive, and we thus have not done any histopathological studies.

The current approach to the relief of chronic pain involves either modification of efferent nociceptive impulses or alternation of the central interpretation of those impulses. Nevertheless, when an organic cause exists, nerve blockade generally plays a major role in pain management.

Despite its popularity, continuous epidural anaesthesia, either by infusion or by intermittent doses, is technically complicated, time-consuming and expensive. Furthermore, it may cause neurological toxicity or other complications. ${ }^{17,18}$ Thus, it would be advantageous if this slow drug release formulation could replace the continuous technique in certain clinical situations.

In conclusion, epidural administration of bupivacaine in glycerin prolongs its analgesic effects. The slow drug release formulation, in addition to relief of chronic pain, may also have other clinical applications, such as the relief of labour pain or postoperative pain. If the quality of analgesia is sufficient, it may well be useful for surgical anaesthesia. This slow drug release formulation approach is worthy of further investigation.

\section{References}

1 Maher RM. Relief of pain in incurable cancer. Lancet 1955; 1: 18-20.

2 Huskisson EC. Measurement of pain. Lancet 1974; 2: 1127-31.

3 Aun C, Lam YM, Collett B. Evaluation of the use of visual analogue scale in Chinese patients. Pain 1986; 25: 215-21.

4 Bromage PR, Burfoot MF, Crowell DE, Pettigrew RT. Quality of epidural blockade I:Influence of physical factors. Br J Anaesth 1964; 35: 342-52.

5 Bruck $S E$ (Ed.). Controlled Drug Delivery. Vol I. Boca Raton, Florida: CRC Press, Inc., 1983; 143-5.

6 Gidez LI, Karnovsky ML. The metabolism of $\mathrm{C}^{14}$. glycerol in the intact rat. J Biol Chem 1954; 206: 229-42.

7 Oakley DE, Ellis $P P$. Glycerol and hyperosmolar nonketotic coma. Am J Opthalmol 1976; 81: 469-72.

8 Heinemeyer $G$. Clinical pharmacokinetic considerations in the treatment of increased intracranial pressure. Clin Pharmacokinet 1987; 13: 1-25.

9 Kirchner FR, Toledo PS, Svoboda DJ. Studies of the larynx after Teflon injection. Arch Otolaryngol 1966; 83: $350-4$.

10 Lewy $R B$. Responses of laryngeal tissue to granular Teflon in situ. Arch Otolaryngol 1966; 83: 355-9.

11 Weingarten $C Z$. Injection of the pterygopalatine fossa with glycerin for posterior epistaxis. Transactions of the American Academy of Opthamology \& Otolaryngology 1972; 76: 932-7. 
12 Lewy $R B$, Mathews $R$. Immediate temporary restoration of the glottic valve function. Laryngoscopy 1965; 75 : 1348-51.

13 Burchiel KJ. Percutaneous retrogasserian glycerol rhizolysis in the management of trigeminal neuralgia. J Neurosurg 1988; 69: 361-6.

14 Langerman L, Golomb E, Benita $S$. Spinal anesthesia: significant prolongation of the pharmacologic effect of tetracaine with lipid solution of the agent. Anesthesiology 1991; 74: 105-7.

15 Langerman L, Grant GJ, Zakowski M, Golomb E, Ramanathan $S$, Turndorf $H$. Prolongation of epidural anesthesia using a lipid drug carrier with procaine, lidocaine and tetracaine. Anesth Analg 1992; 75: 900-5.

16 Mashimo T, Uchida I, Pack M, et al. Prolongation of canine epidural anesthesia by liposome encapsulation of lidocaine. Anesth Analg 1992; 74: 827-34.

17 Maier C. Wawersik J, Wulf $H$. Risks in postoperative pain therapy using a peridural catheter in a normal general ward. Anaesth Intensivther, Notf Med 1986; 21: 72-7.

18 Dunne NM, Kox WJ. Neurological complications following the use of continuous extradural analgesia with bupivacaine. Br J Anaesth 1991; 66: 617-9. 